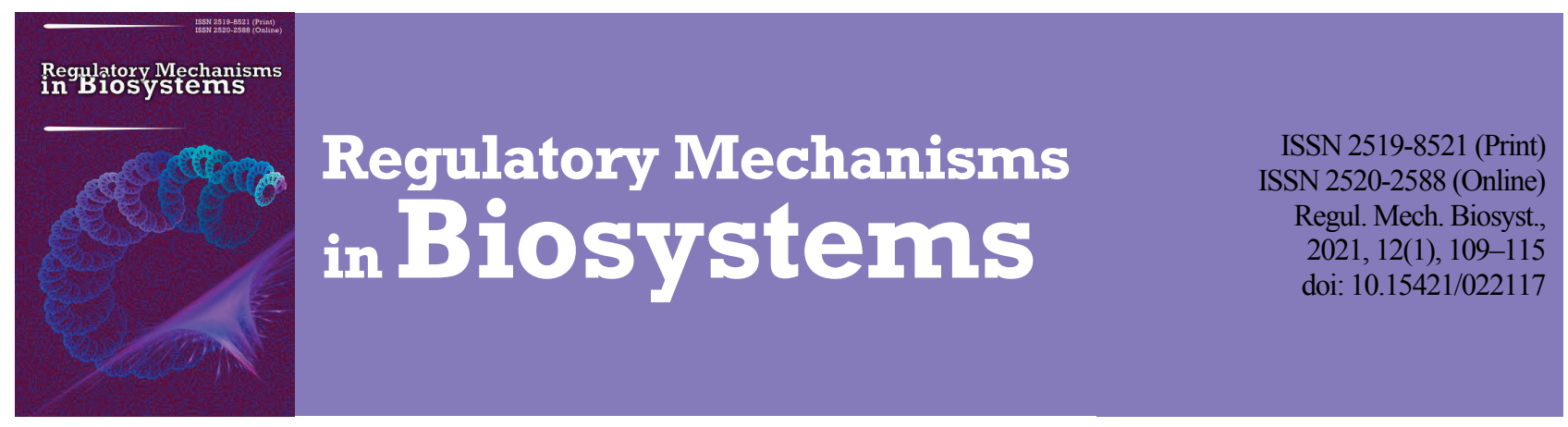

\title{
Application of enzyme probiotic drug developed based on microorganisms of the ru- men of reindeer (Rangifer tarandus) in feeding cows
}

\author{
A. S. Litonina*, Y. M. Smirnova*, A. V. Platonov*, G. Y. Laptev**, T. P. Dunyashev**, M. V. Butakova*** \\ *Vologda Research Center of the Russian Academy of Sciences, Vologda, Russia \\ ** "Biotrof+" Ltd, Saint Petersburg, Russia \\ *** Vologda State University, Vologda, Russia
}

Article info

Received 24. 12.2020

Received in revised form 27.01.2021

Accepted 28.01.2021

Vologda Research Center of the Russian Academy of Sciences, Gorky st., 56A, Vologda, 160014, Russia. Tel.: + 7-817-259-78-10 E-mail:

platonov70@yandex.ru

"Biotrof +" Ltd, Zagrebskii bulv., 19/1,

Saint Petersburg,

192284, Russia.

Tel: +7-812-322-85-50.

E-mail:lapter@biotrof.ru

Vologda State University,

Pobedyav., 37,

Vologda, 160001, Russia.

Tel.: +7-817-272-13-77.

E-mail:butakovam@@

vogu35.ru

\section{Introduction}

Modern industrial animal husbandry, especially dairy livestock, usually has demanding regimes of the production processes that overload the functional activity of the systems of the animals' organisms (Romanov et al., 2019). When the zoohygienic rules of feeding and maintenance of animals are violated, the natural resistance of the organism, as well as their resistance to unfavourable environmental factors, decrease. This leads to growing morbidity, increase in the number of infectious, allergic, autoimmune and other pathologies. Against the background of deterioration of the ecological situation, there occur changes in pathogenesis and clinical course of various diseases, and the percentage of atypical and mild forms increases, and the chronization of the process occurs more often. In livestock breeding, the medical and preventive measures against diseases of infectious and non-infectious etiologies entail the use of a large amount of medical preparations. Antibiotics in agriculture have been usually used in livestock breeding for the prevention of bacterial infections and stimulation of growth of cattle (Nesme et al., 2015).

Broad, and not always justified, application of those preparations is accompanied by development of drug-resistance among microorganisms in the animals. According to the studies by Godziszewska et al. (2018), strains of coliform bacteria isolated from raw cow milk were resistant to a number of antibiotics used in veterinary medicine: penicillin (88\%), kanaline (55\%). Moreover, use of antibiotics in livestock may pose a threat to human health (Wemette et al., 2012). According to the 2019 report, in the USA, $2.8 \mathrm{~m}$ antibiotic-resistant infections emerge daily, causing death to over 35,000 people (Alter et al., 2019). Since January 1, 2016, the European Union has completely prohibited the use of stimulatory antibiotics in animal fodders. The prohibition has been introduced to all the countries of the EU. Since then, antibiotics were allowed to be used only as medical preparations (Casewell et al., 2005).

Thus, the search for new, more efficient preparations that develop no resistance in microorganisms and have a notable antimicrobial impact, including action against antibiotic-resistant microbial strains, is quite relevant in both human and veterinary medicines. Study of the patterns in relations between animals and microbiota led to the development of a principally new class of preparations that allow the use of the biological potential of the organism accumulated over the process of co-evolution of bioorganisms. Since the 1990s, probiotics have been successfully applied to correct microbiocoenoses in the intestine and as effective antimicrobial preparations. Probiotic preparations that contain strains of live bacteria isolated from the gastro-internal tract of animals cause not only the development and activities of beneficial simbiont microflora, but also inhibit the growth of pathogenic and conditionally pathogenic strains of microorganisms. Probiotic preparations are broadly used to improve digestion pro- 
cesses, increase the efficiency of feeds, improve metabolic processes, and also for preventive measures, to treat gastrointernal infectious and noninfectious diseases that occur as a result of sudden changes in the composition of the diet, violation of feeding regimes, technological stresses, reestablishment, correction of symbiont microflora of the digestive tract after treatment with antibiotics and antibacterial chemopreparations, and also as a substitute of antibiotics, for stimulation of non-specific immunity, and for growth of productivity of animals in general (Liu et al., 2015; Yu et al., 2016; Ma et al., 2018).

The term "probiotic" was used for the first time by Ferdinand Vergin in 1954 (Biernasiak et al., 2011). In that same year, the scientist compared the deleterious actions of antibiotics and other antimicrobial substances toward the flora with the positive effect of probiotics that was induced by beneficial bacteria. In 1974, Parker used this term for the substances that contribute to the balance of intestinal microflora of the host (Parker et al., 2014). The currently used definition was proposed by the WHO in 2002. The food organization of the UN defines probiotics as live organisms that provide the host with health advantages when introduced in sufficient amount (Biernasiak et al., 2011). Microorganisms used in animal feeding comprise mainly Gram-positive bacteria belonging to the genera Bacillus, Enterococcus, Lactobacillus, Streptococcus and yeasts of the Saccharomycetes genus (Boris et al., 2005). The earliest probiotic still broadly used today in animal feeding is based on silage, the benefits of which has been proven by many years of use (Biernasiak et al., 2011). Modern probiotic preparations should be subjected to integrated testing in correspondence with the regulation of the Commission 94/40/EU as of 22 July, 1994 defining the procedures of evaluation of additives to animal diets.

Probiotics influence bacteria of the GIT by increasing the amount of beneficial anaerobic bacteria and decreasing the populations of potentially pathogenic microorganisms. Probiotics affect the GIT ecosystem by influencing the immune mechanisms in the mucous membrane, interacting with symbiotic or potentially pathogenic microbes, generating metabolic products such as short-chain fatty acids, and commutate with the host cells using chemical signals. Those mechanisms may lead to improvement in the GIT environment, strengthening of the gastrointestinal barrier, feedback from the immune response to antigen calls (Biernasiak et al., 2011; Guarner, 2017). An effective probiotic should contain no pathogens and be non-toxic, able to transfer the gastric acid and stick to the epithelium of the intestine, as well as produce antimicrobial substances. Furthermore, it should stay in the gastrointestinal tract long enough to have a positive effect (Angelakis et al., 2017). Possible mechanisms of cross-influence such as probiotic-host and probiotic-microbiota may be divided into three main categories: direct interaction with the host's cells, inhibition of growth of pathogens and modulation of immune responses of the host (Bajaj et al., 2015; Angelakis, 2017).

Today, there is a large amount of scientific-practical material on the application of probiotic and complex enzyme probiotic preparations in feeding animals and poultry (Pereirf et al., 2019; Yadar et al., 2019). New preparations for agricultural animals for increasing benefits from livestock production are currently in development. Therefore, in feeding dairy cows, Valitova (2014) used the probiotic supplement Vetosporin-Acktiv. The application of the probiotic during a hundred days of lactation resulted in the highest milk yields from the cows of the experimental groups. The values of the studied parameter in the experimental groups exceeded those of the control group by $2.4-5.1 \%$. The values that characterize the mass share of protein and its constituents indicate that introduction of Vetosporin-Aktiv probiotic preparation to the diet in the dosage of $100 \mathrm{~g} / \mathrm{T}$ of fodder increased the level of dairy productivity and improved the qualitative characteristics of milk (Valitova et al., 2014).

Studies by foreign authors also report a positive effect of probiotic preparations on the organisms of animals. The study by Schofield (2018) indicates that the probiotic Bacillus amyloliquefaciens H57increased food intake and live weight in ruminants (Schofield et al., 2018). Oh et al. (2019) studied the influence of a microbiological preparation (SDM) based on Saccharomyces cerevisiae and exogenous enzyme product (ENZ) on the emissions of methane in the intestine, milk yield and the composition of milk, digestion of nutrients in the gastrointernal tract and also production and secretion of nitrogen in lactating dairy cows. As a result of the experiments, milk yield in the experimental group that re- ceived SDM, compared with the control, increased by $2 \mathrm{~kg} /$ day. Addition of EZN to the diet had no effect on the milk yield and efficiency of feed digestion. The concentration of major volatile fatty acids (VFA) in the rumen liquid was increased both using SDM and EZN, while $\mathrm{pH}$ of the rumen was reduced using SDM compared with the control. Increased concentration of VFA in the rumen liquid of cows that received SDM indicates increased postruminal reserve of energy and may partly explain the increased milk yield (Oh et al., 2019). Intensive production technology is accompanied by tension in the functions of all of the organs, and the most intense period that determines the health and productivity of the animals is the transitional period. Therefore, Al Zahal et al. (2014) performed and analysis of influence of microbiological preparation (DFM) on the consumption of dry matter, milk yield, milk components, the morbidity rate and metabolites in the blood of dairy cattle in the transitional period and also digestion of the nutrients. Feeding with the preparation was started three weeks before the calving and ended 10 weeks after the calving. The results revealed that DFM had a positive effect on digestibility of the fodders in the digestive tract (Al Zahal et al., 2014).

Thus, it is necessary to introduce probiotic additives as broadly as possible as a cheap, multi-fold cost-effctive method of increasing productivity and quality of livestock products. Monitoring of the market of probiotics indicates that most modern probiotics are quite efficient, but at the same time are not popular in the practice due to their high cost. Therefore, dairy livestock breeding needs development of cheap and effective preparations of probiotic action (Smirnova et al., 2020).

One of such new generation preparations is the enzymatic probiotic Tsellobacterin+, developed and produced by Biotrof + Ltd (Saint Petersburg, Russia). Tsellobacterin+ is a spore-forming strain of live bacteria of Enterococcus sp. 1-30 that act as a feed enzyme and probiotic (Laptev et al., 2014). Application of Tsellobacterin+ contributed to increase in the content of beneficial cellulolytic bacteria and decrease in the representatives of unfavourable microflora (Lactobacillus, Enterobacteriaceae, Clostridium) and pathogens - Fusobacterium, Staphylococcus, Campylobacter and Peptococcus), and also Pseudomonas compared with the control. At the same time, the study revealed that the probiotic successfully increased cellulose activity of the contents of the rumen and strengthened the cud chewing. Overall, the application of Tsellobacterin + to the diet led to increase in food consumption: by $3.6 \%$ in the group of early dry period, $5.3 \%$ in the group of late dry period, by $20.2 \%$ in heifers and $3.6 \%$ in milked cows. Normalization of the composition of microflora of the rumen of cows (increase in the share of cellulolytic bacteria and decrease in the content of pathogens) under the effect of the preparation positively influenced the level of dairy productivity of the animals. The results of the studies indicated that the increase in the average daily milk yield accounted for $2.8 \mathrm{~L}$, increase in the fat content was $0.19 \%$ and in protein content $0.12 \%$ compared with the control, therefore the additional profit would equal \$1.02 from an individual per day. Furthermore, the amount of somatic cells in the milk of the cows decreased (Romanov et al., 2019).

Over the recent years, researchers have been drawing great attention to the ability of microorganisms to biodestruct bacterial and fungal toxins to non-toxic compounds in order to develop highly effective biopreparations (Cho et al., 2009; Reddy et al., 2009). The efficacy of biotransformation of toxin is presumably due to the great metabolic lability of microorganisms: great variety of enzymic systems, synthesis of organic acids and various other compounds (Abrunhosa et al., 2014). According to a number of scientists, bacteria associated with the rumen of deer may perform active detoxication of the usnic acid (Sundset et al., 2009; Luzina et al., 2016) and mycotoxins (Burkin et al., 2014) present in the components and diets.

In this connection, Biotrof + Ltd Company screened highly effective isolates from the rumen contents of Rangifer tarandus to collect bacteria with cellulolytic and antimicrobial properties and also ability to biodestruct micotoxins as the base for highly effective preparation for breeding of deer and other types of livestock. Based on the surveys, the Rumit biopreparation was developed, the action of which has not been studied until now.

The objective of the study was determining the peculiarities of the effect of the enzyme probiotic preparation Rumit developed based on microorganisms of the rumen of reindeer (Rangifer tarandus) on dairy productivity and physiological parameters of health of cows, population and 
generation diversity of rumen protists, as well as costs for feed in milk production.

\section{Materials and methods}

The experiments were performed in autumn-winter of 2019-2020 at the Department of Breeding Holsteinized Russian Black Pied Cattle at the Breeding Plant of the Agricultural Industrial Cooperative the Peredovoi Kolkhoz (Vologda Oblast, Russia). All the manipulations with the experimental animals were performed according to the rules of the European Convention for the Protection of Vertebrate Animals used for Experimental and Other Scientific Purposes (Official Journal of the European Union L276/33, 2010). In the process of production experiments, the probiotic Rumit ("Biotrof + "' Ltd, Russia, 2019) was tested. The probiotic is safe for feeding cattle, contains no conditionally pathogenic or pathogenic microflora, including Pseudomonas aeruginosa, Enterobacteriaceae, Staphylococcus aureus, Candida albicans.

To perform the experiment, we formed two groups (control and experimental) of first-calf heifers with 12 individuals in each. The animals were selected using the method of balanced groups. Criteria of selection were such signs as milk yield of mothers for maximum lactation, thorough-bred quality according to the Holstein breed, live mass, number of milking days and daily milk yield at the beginning of the experiment.

The experimental animals were kept tied at current workshop technology. The animals were kept separately, both the control and experimental groups, in the same conditions, corresponding to the norms of zoohygienic control.

According to the scheme of the experiment, first-calf heifers of the experimental group, in addition to the main diet, received the Rumit supplement in the dose of $50 \mathrm{~g}$ per individual every day at the lunchtime feeding. The experiment lasted 110 days: 20 days of the preparation period and 90 days of the account.

According to the detailed norms of Kalashnikov (2003), all the animals depending on fat mass, physiological condition, productivity and age, received the main diet taking into account the chemical composition of local feeds. To determine how substantial was the feeding, we selected samples of feeds included in the diet of the experimental groups for chemical analysis before the experiment and during change of the fodders (dry matter, raw and digestible protein, calculation of metabolic energy, ash, cellulose, sugar, starch, fat, carotene, NFE (nitrogen free extracts), calcium, phosphorus, sodium and potassium contents). Sampling, analysis and the control of the feeds were performed using the methods of the L. K. Ernst Federal Research Center for Animal Husbandry.

The feeding on the farm was conducted two-times a day using horizontal auger. During the scientific-economic experiment, the animals of the experimental groups received agricultural diet as a feed mixture. The main types of food included in the diet were silage and hay from various grasses, haylage of barley, sunflower press cake, maize, soybean, barley, soybean grist, premix, maltodextrin and salt.

Analysis of diet of heifers with daily milk yield of $34 \mathrm{~kg}$ in first 100 days of lactation after calving indicated that it was balanced according to the main nutrients at both the beginning and the end of the experiment (Table 1).

\section{Table 1}

Qualitative characteristics of the diet of experimental animals

\begin{tabular}{lcc}
\hline \multicolumn{1}{c}{ Parameters } & Norm & Actual \\
\hline Concentration of energy, MJ/kg of dry matter & $10-18$ & 10.6 \\
Sugar-protein ratio & $0.8-1.5$ & 0.6 \\
Dry matter per 100 kg of live weight, kg & $3.5-4.5$ & 4.4 \\
Sodium/potassium & $0.3-0.5$ & 0.8 \\
Calcium/phosphorus & $1.5-2.1: 1$ & 0.8 \\
Dry matter of the diet contains, \% & & \\
Digestible protein & $10-15$ & 10.6 \\
- sugar & $6-12$ & 6.7 \\
- cellulose & $23-19$ & 16.6 \\
- fat & $2-6$ & 4.0 \\
Costs for feeds per 1 kg of milk, fodder units & $0.85-0.95$ & 0.69 \\
\hline
\end{tabular}

The dairy productivity was evaluated using the method of control milking, according to the parameters of the milk yield, mass share of fat and protein. The analysis of quality of feeds and milk was performed at the North-West Scientific Research Institute of Dairy and Meadow-Pasture Agriculture.

The whole blood was drawn from beneath the caudal vein at the beginning and the end of the experiment from 5 individuals of each group for the evaluation of completeness of feeding and the health condition. Hematological and biochemical blood assays were carried out on automatic blood analyzers using reagents manufactured by Diakon-Vet (Russia, 2019). Phagocytosis was assessed according to such parameters as phagocytic number (microbial bodies), phagocytic index (microbial bodies) and phagocytic activity of neutrophils (\%). Phagocytic activity is the percentage of phagocytic neutrophils in the total number of the counted ones. Phagocytic index is the number of absorbed microbial cells (m.c.) recounted as one neutrophil of the overall number of counted neutrophils. Phagocytic number is the number of microbial cells in re-count to one active (phagocytic) neutrophil.

The samples of the rumen were taken at the beginning and the end of the experiment from 5 individuals of each group according to the method of Kurilov (1972) 2-3 h after the feeding using a mouth gag. The protists were counted in the Fuchs-Rosenthal chamber. This chamber is deeper than the Goryaev's chamber, and it can esily accommodate large ciliates. To count the ciliates, we used Micromed-2 microscope (China). The genera were identified according to the Dogel's Ciliophora identification tables (1929). The population was analyzed according to the study by Pesenko (1982) as the ratio of relative abundances, genera included in them $\left(p_{i}\right)$ - shares of separate genera in the overall number of individuals of all genera.

When subjecting the animals to the experiment and at the end of it, we assessed physiological indicators of the condition of 5 animals of each group such as the body temperature, respiration frequency, pulse, and rumen contractions. At the beginning of the experiment, the obtained data confirmed the health of the experimental animals.

At the end of the experiment, we observed behavioural reactions of three animals in each group using the methods of monitoring and individual chronometry of Venidiktova (1982). For $24 \mathrm{~h}$ during the two subsequent days we monitored the feeding behaviour of the experimental animals. At the same time, we took into account duration of the following elements of the behaviour for each animal: food intake, chewing the food, motor (standing), rest (lying and sleep), and water intake. Of the overall time (1,440 min.), we calculated the time that was spent on the said behaviour elements in absolute and percentage expressions. Furthermore, for the assessment of the feeding behaviour of the animals, we calculated the following indices: feeding, motor and overall activity. The indices of the functional activity were calculated as the ratio of time spent on one or the other type of motor activity to the total amount of time, expressed in minutes.

The data in the tables are presented as mean values and their standard deviations $(\mathrm{x} \pm \mathrm{SD})$. Statistical reliability of the obtained data was determined according to the data of ANOVA at the significance level of $\mathrm{P}<0.05$.

\section{Results}

Mean daily milk yield from cows of the experimental group that received the feed probiotic in the amount of $50 \mathrm{~g}$ per individual a day equaled $31.5 \mathrm{~kg}$ of milk, which was $8.6 \%$ higher than in the control (Table 2).

In recalculation to yield of natural milk, the cows of the experimental group were observed to produce more milk of natural fat content than the control group, by $207 \mathrm{~kg}$ for 90 days of the experiment. The fat output in the experimental group was reliably $(\mathrm{P}<0.05)$ higher than the control by $11.4 \%$, or by $9.6 \mathrm{~kg}$, and the output of protein - by $10.3 \%$, or $7.7 \mathrm{~kg}$. For more objective comparison, we calculated the average daily yield of $4 \%$-fat milk, which was $11.5 \%$ higher in the experimental group of firstcalf heifers than the control.

Increases in the productive qualities of animals that had been fed with the enzyme probiotic preparation had a positive effect on expenditures of feeds and energy per $1 \mathrm{~kg}$ of $4 \%$-fat milk (Table 3 ).

The animals involved in the experiment consumed an agricultural diet that contained 23.6 EFU, 22 food units, $22.2 \mathrm{~kg}$ of dry matter and 2,349 $\mathrm{g}$ of digestible protein. Expenditures of metabolic energy in lactating cows 
when consuming Rumit were $10.3 \%$ lower compared with the control group. According to the expenditures of food units of the diet per $1 \mathrm{~kg}$ of $4 \%$-fat milk, the control group exceeded the experimental group by $10 \%$. The animals that received the Rumit additive expended $84 \mathrm{~g}$ less dry matter and $9 \mathrm{~g}$ less digestible protein on production than the control group.
According to the expenditures of digestible protein per $1 \mathrm{~kg}$ of $4 \%$-fat milk, the control group exceeded the experimental one by $10.8 \%$.

Inclusion of the food supplement in the diet of animals of the experimental group led to $155,900 \mathrm{ind} . \mathrm{mL}$, or 3-fold, increase in density of their ciliate fauna during the experiment (Fig. 1).

Table 2

Parameters of dairy productivity in first-calf cows $(\mathrm{x} \pm \mathrm{SD}, \mathrm{n}=12)$

\begin{tabular}{|c|c|c|c|c|c|c|c|}
\hline Groups & $\begin{array}{l}\text { Mean daily } \\
\text { milk yield, kg }\end{array}$ & $\begin{array}{l}\text { Total milk yield for the period } \\
\text { of the experiment, } \mathrm{kg}\end{array}$ & $\begin{array}{l}\text { Mass share } \\
\text { of fat, } \%\end{array}$ & $\begin{array}{l}\text { Mass share } \\
\text { of protein, } \%\end{array}$ & $\begin{array}{l}\text { Daily yield of } \\
\text { 4\%-fat milk, } \mathrm{kg}\end{array}$ & $\begin{array}{l}\text { Total output of dairy fat for the } \\
\text { period of the experiment, } \mathrm{kg}\end{array}$ & $\begin{array}{l}\text { Total output of dairy } \\
\text { protein for the period } \\
\text { of the experiment, } \mathrm{kg}\end{array}$ \\
\hline Control & $28.8 \pm 1.0$ & $2253 \pm 83$ & $3.75 \pm 0.07$ & $3.31 \pm 0.05$ & $27.0 \pm 1.0$ & $84.4 \pm 3.1$ & $74.4 \pm 2.3$ \\
\hline Experimental & $31.5 \pm 1.2$ & $2460 \pm 89$ & $3.82 \pm 0.07$ & $3.34 \pm 0.05$ & $30.1 \pm 1.2^{*}$ & $94.0 \pm 3.7^{*}$ & $82.1 \pm 3.0^{*}$ \\
\hline
\end{tabular}

Note: *-difference compared with the control is statistically significant at $\mathrm{P}<0.05$.

Table 3

Energy expenditures for $1 \mathrm{~kg}$ of $4 \%$-fat milk $(\mathrm{n}=12)$

\begin{tabular}{lcc}
\hline \multirow{2}{*}{ Parameters } & \multicolumn{2}{c}{ Groups } \\
\cline { 2 - 3 } & control & experimental \\
\hline Mean daily 4\%-fat milk yield, kg & 27.0 & 30.1 \\
Fodder units, g & 0.81 & 0.73 \\
Metabolic energy, EFU (energy fodder unit) & 0.87 & 0.78 \\
Dry matter, g & 822 & 738 \\
Digestible protein, g & 87 & 78 \\
\hline
\end{tabular}

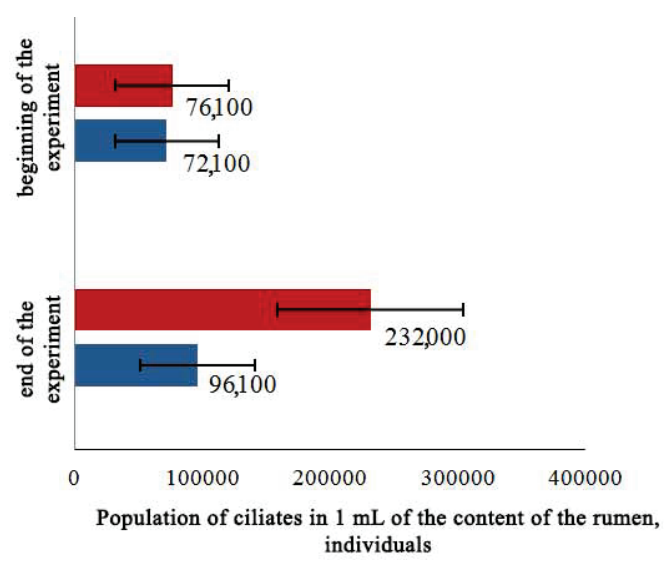

Fig. 1. Effect of the probiotic preparation on the ciliate population in the contents of the cows' rumen $(x \pm S D, n=5)$ : blue - the control group, red - the experimental group

Compared to their agemates of the control group, at the end of the experiment, the difference equaled $135,000 \mathrm{ind} / \mathrm{mL}$. At the beginning of the experiment, the dominating group of microbiota in the cows' rumen of both groups was represented by Entodinium genus, comprising 77.8 $100 \%$ of the population of ciliates. The share of the Diplodinium genus in animals of the experimental group was $6.6 \%(5,000 \mathrm{ind} . / \mathrm{mL})$, that of the Dasytricha genus ranged starting from $2.5 \%(1,900 \mathrm{ind} / \mathrm{mL})$. The remaining genera were low-numbered, equaling in total less than $1.0 \%$ of the population of ciliates (Table 4).

At the end of the experiment, in the population of ciliates in the rumen of the cows of the control group, we found four genera of ciliates, and in their agemates of the experimental group, in addition, a fifth genus - Epidinium - was found. Among the mentioned ciliates, the dominant genus was Entodinium, comprising 92.0\% to $92.2 \%(88,700-21,3200 \mathrm{ind} . / \mathrm{mL})$. The remaining genera were overall relatively abundant ranging $8.6 \%$ in the cows of the experimental group to 7.8 in their agemates in the control group. In the experimental group, we observed significant increases in the density of particular genera: Entodinium by 124,500 ind./mL, Diplodinium - 2,000 ind. $/ \mathrm{mL}$, Dasytricha - 3,000 ind. $/ \mathrm{mL}$, Isotricha $4,400 \mathrm{ind} / \mathrm{mL}$.

The animals which consumed Rumit food additive spent more time on consumption of food -25 min compared with the control group $(6.9 \%$, Table 5). The duration of cud chewing in the experimental group that received Rumit with the main diet increased by $12 \mathrm{~min}(2.7 \%)$. This group was observed to have higher number of chewing movements compared with the control group, by $259 \mathrm{~min}(3.2 \%)$.This is confirmed by the number of contractions of the rumen, a parameter that in the experimental group was $6.3 \%$ higher than the control. The animals of the experimental group had $0.026(4.5 \%)$ higher feeding activity as compared with the control group.

Table 4

Density of ciliates in the cows' rumen in $1 \mathrm{~mL}$ of the rumen liquid, individuals $(\mathrm{x} \pm \mathrm{SD}, \mathrm{n}=5)$

\begin{tabular}{|c|c|c|c|c|}
\hline \multirow{3}{*}{$\begin{array}{c}\text { Genus } \\
\text { of ciliates }\end{array}$} & \multicolumn{4}{|c|}{ Groups of animals } \\
\hline & \multicolumn{2}{|c|}{ control } & \multicolumn{2}{|c|}{ experimental } \\
\hline & $\begin{array}{l}\text { beginning of } \\
\text { the experiment }\end{array}$ & $\begin{array}{l}\text { end of the } \\
\text { experiment }\end{array}$ & $\begin{array}{l}\text { beginning of } \\
\text { the experiment }\end{array}$ & $\begin{array}{l}\text { end of the } \\
\text { experiment }\end{array}$ \\
\hline Entodinium & $72100 \pm 40400$ & $88700 \pm 44500$ & $72900 \pm 42500$ & $213200 \pm 67500^{*}$ \\
\hline Diplodinium & 0 & $6000 \pm 2300$ & $5000 \pm 100$ & $8000 \pm 2900$ \\
\hline Epidinium & 0 & 0 & 0 & $1830 \pm 1200$ \\
\hline Dasytricha & 0 & $800 \pm 200$ & $1900 \pm 1200$ & $3800 \pm 1900^{*}$ \\
\hline Isotricha & 0 & $600 \pm 100$ & $600 \pm 100$ & $5000 \pm 100^{* * *}$ \\
\hline
\end{tabular}

Note: * - difference compared with the control is statistically significant at $\mathrm{P}<0.05$, *** - difference compared with the control is statistically significant at $\mathrm{P}<0.001$.

Table 5

Results of time measurement of the behavioural reactions of first-calf heifers $(\mathrm{x} \pm \mathrm{SD}, \mathrm{n}=3)$

\begin{tabular}{lcc}
\hline \multicolumn{1}{c}{ Behavioural reactions } & \multicolumn{2}{c}{ Groups of animals } \\
\cline { 2 - 3 } & control & experimental \\
\hline Feeding, min & $789 \pm 16$ & $826 \pm 42$ \\
$\quad$ - including consumption of food & $363 \pm 9$ & $388 \pm 30$ \\
$\quad$ - chewing the food while standing & $140 \pm 30$ & $148 \pm 30$ \\
$\quad$ - chewing the food while lying & $286 \pm 32$ & $290 \pm 32$ \\
Moving, min & $305 \pm 39$ & $278 \pm 38$ \\
Stops, min & $345 \pm 27$ & $335 \pm 67$ \\
Number of chewing movements & $7960 \pm 599$ & $8219 \pm 553$ \\
Contractions of the rumen, times per 2 min & $3.2 \pm 0.3$ & $3.4 \pm 0.2$ \\
Number of water intakes & $39 \pm 10$ & $35 \pm 13$ \\
Index of feeding activity & $0.548 \pm 0.011$ & $0.574 \pm 0.029^{*}$ \\
Index of motor activity & $0.212 \pm 0.027$ & $0.193 \pm 0.027$ \\
Index of the general activity & $0.760 \pm 0.019$ & $0.767 \pm 0.047$ \\
\hline
\end{tabular}

Note: *-difference compared with the control is statistically significant at $\mathrm{P}<0.05$.

By the end of the experiment, the content of total protein in blood of cows of the experimental group was several times higher compared with the control, mainly due to albumin fraction that increased by $2.2 \%$ in blood of cows of the experimental group (Fig. 2).

In the experimental group, we observed growth of the concentration of glucose in blood to the normal values (3.28-3.77 $\mathrm{mmol} / \mathrm{L}$ ) and, therefore compared with the control, this difference equaled $0.29 \mathrm{mmol} / \mathrm{L}$ (8.6\%, Fig. 3).

The content of urea in blood of cows that received the probiotic supplement in addition to their diet was $0.7 \mathrm{mmol} / \mathrm{L}$ lower than that of those in the control. In the performed monitoring, we found no significant differences between the blood cholesterol in the experimental and control groups, though there was a slight decrease $(1.7 \%)$ in this parameter in the blood of cows that received the biopreparation in addition to their diet. Furthermore, we observed that in both the analyzed groups of cows, the cholesterol blood content was $0.77-0.87 \mathrm{mmol} / \mathrm{L}$ higher than the reference values. 


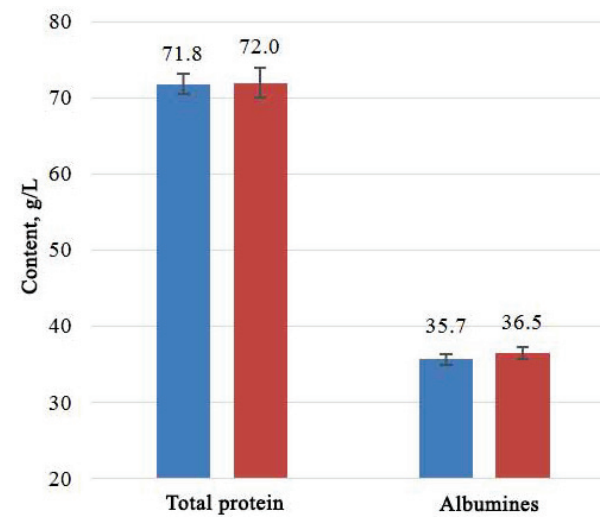

Fig. 2. Effect of Rumit probiotic on the content of the total protein and albumins in the blood of cows $(\mathrm{x} \pm \mathrm{SD}, \mathrm{n}=5)$ : blue - control group, red - experimental group

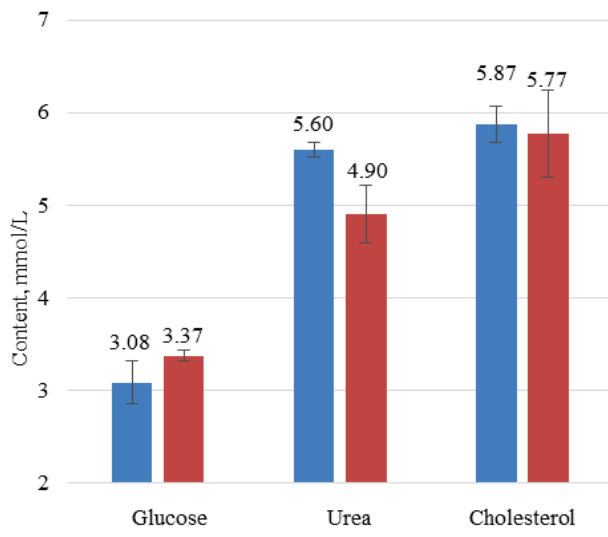

Fig. 3. Effect of use of the preparation on content of glucose, urea, and cholesterol in the blood of cows $(x \pm S D, n=5)$ :

blue - control group, red-experimental group

Clinical parameters of animals of the experimental groups were within the range of physiological norm (Table 6).

\section{Table 6}

Physiological parameters and protective properties in the organism of cows $(x \pm S D, n=5)$

\begin{tabular}{lll}
\hline \multicolumn{1}{c}{ Parameter } & \multicolumn{1}{c}{ Control } & \multicolumn{1}{c}{ Rumit } \\
\hline Temperature, ${ }^{~} \mathrm{C}$ & $38.2 \pm 0.1$ & $38.0 \pm 0.1$ \\
Pulse, heartbeats/min & $63.2 \pm 1.9$ & $60.8 \pm 2.3$ \\
Respiration per min & $25.6 \pm 0.9$ & $24.0 \pm 1.2$ \\
Leukocytes (WBC), $10^{9} / \mathrm{L}$ & $21.1 \pm 1.1$ & $16.0 \pm 1.7^{*}$ \\
Granulocytes (GRAN), \% & $47.2 \pm 3.4$ & $55.1 \pm 4.4^{*}$ \\
Phagocytic number, microbial bodies & $5.25 \pm 0.53$ & $7.52 \pm 0.79^{*}$ \\
Phagocytic index, microbial bodies & $1.21 \pm 0.09$ & $2.02 \pm 0.24^{* *}$ \\
Phagocytic activity, \% & $26.4 \pm 1.0$ & $26.6 \pm 2.7$ \\
\hline
\end{tabular}

Note: *-P $<0.05, * *-\mathrm{P}<0.01$ difference compared with the control.

Body temperature in both groups was within the range $38.0-38.2^{\circ} \mathrm{C}$. In the experimental group, the leukocyte number of the cows decreased by $32.0 \%$, and the number of granulocytes increased by $16.6 \%$, and the number of bacteria per one active neutrophil increased by $30.2 \%$, compared with the control. Absorptive ability of neutrophils, as indicated by the value of phagocytic index, also increased by $40.0 \%(\mathrm{P}<0.01)$ in cows that received the probiotic.

\section{Discussion}

The productivity of animals to a great extent depends on fullness of the diet and rational use of biologically active components. Use of probiotic supplements contributes to the increase in activity of the metabolism in cows, leading to growth of the parameters of dairy productivity (Syrtsev et al., 2019a; Vorobieva et al., 2020), particularly milk yield and fat content in milk (Maamouri et al., 2014), and also content of protein in milk
(Haiyan et al., 2017). The conducted research on the efficiency of use of the enzyme probiotic supplement Rumit in feeding newly-calved cows confirms the increase in productive qualities of cows, both regarding milk and separate components. This is likely related to the optimization of metabolic processes in the organism as a result of better digestion of nutrients. Microbes of the rumen allow the ruminants to collect energy as volatile fatty acids by fermentation of indigestible plant material. This energy accounts for about $70 \%$ of metabolic energy the animals consume. Therefore, the microbiome may be a link between the feeding and productivity of the host (Mullins et al., 2014).

Most of the diet's nutrients are subject to complex transformations in the proventriculus. A certain role in these processes is played ciliates. Ciliates mostly take part in the mechanical splitting of cellulose and mixing of food parts in the proventriculus of ruminants, thereby indirectly improving the digestive processes, i.e. the protozoa fauna takes part directly in providing the animal with necessary metabolites, and is a source of highly valuable protein and carbohydrates on itself. Use of the Rumit preparation in the research described here, contributed to the growth of the number of ciliates in the rumen. Also, in the samples of lactating cows of the experimental groups, we observed a quite wide diversity of protists. In the surveyed content of the rumen, we recorded ciliates at the stage of division, indicating optimum parameters of its functioning.

The peculiarity of the feeding reactions of cattle and their digestive system is the multi-times regurgitation of food bolus and its prolonged chewing. Duration of cud chewing positively influences the digestibility and metabolism of the food the animals consume. Lactating cows with heightened productivity were observed to have a proportionate decrease in rest time and significant increase in the duration and rates of food consumption (Lagun, 2015). Inclusion of the Rumit probiotic additive to the diet of fresh cows led to an increase in the time spent on consumption of food and cud chewing, elevation in the rate of contractions of the rumen and feeding activity in general, which is coherent with the results of the observations by a number of authors (Gulyaeva, 2012; Lagun, 2015). This once again confirms that intake of food supplements has positive effects on the digestive status of the animals (Yuan et al., 2014).

While studying biochemical parameters of the blood serum of the animals, the biopreparation was seen to have positive effects on metabolic processes in the organism of fresh cows. The main parameter that sufficiently reflects the physiological processes in the organism of animals is blood protein. In the conducted researches, the provision of cows with blood protein indicates absence of lack of protein in the diet of dairy cows and its good digestion. Although these differences were not statistically significant, they may be associated with activation of the processes of synthesis and restoration of proteins, and also more intense use of aminogroups not for the development of urea, but for the synthesis of other compounds in cows that consumed probiotic (Gerasimenko et al., 2015). Glucose is an important source of energy for ruminants. The obtained data suggest that application of Rumit probiotic increased the content of glucose in the blood of the animals to the normal values, thus providing their organism of animals with a sufficient amount of energy for metabolic processes, which is consistent with the results obtained by other authors (Vorobyova et al., 2020). An interesting opinion was expressed by Syrtsev (2019), who points out that normalization of glucose in the blood of experimental animals is explained by normalization of symbiotic microflora as a result of displacing pathogen microorganisms and reducing the toxic effect of mycotoxins on the pancreas (Syrtsev, 2019b). The amount and quality of protein in the diet, and also concentration of ammonia in the rumen can be controlled according to the level of urea in an animal's blood. A decrease was observed in the content of urea in the blood of experimental cows, indicating increase in the efficiency of nitrogen fodder for the synthesis of microbial protein (Nekrasov et al., 2013).

An important biochemical blood indicator is cholesterol. Our research reports an insignificant decrease of cholesterol in the blood of cows that received the biopreparation with their diet, compared with the control group. Furthermore, in both groups of animals, the studied parameter exceeded the normative values, which may have been related not only to intensification of metabolism, but also the increase in the amount of the glandular tissue after calving. An important condition for metabolism and the main factor that provides the normal level of oxidative-restorative 
process in the organism on the whole is the stability of the animal's body temperature. The intensity of metabolism and the environmental temperature are the factors on which the frequency of animals' respiratory movements depends (Markin, 2016). In our studies, we observed normalization of body temperature and respiration frequency in the experimental groups of animals.

It is crucial in evaluating the protective abilities of the organism, to monitor the content of leukocytes in the blood, which characterize the presence of inflammatory processes in the animal's organism. In our studies, use of the Rumit probiotic in feeding resulted in decrease in the number of leukocytes in the blood of animals of the experimental group. Such situation was also observed in the studies by Farkhutdinov where application of a probiotic preparation stimulated hematopoiesis and improved morphological parameters of the blood in animals (Farkhutdinov, 2020). Other than content of leukocytes in blood, the study analyzed the phagocytic activity of neutrophils. Application of the probiotic contributed to elevation of the level of phagocytic capacity of neutrophils in the blood of cows, as indicated by significant increase in the phagocytic number and index in the experimental animals and absence of significant changes in the animals of the control groups (Masalov, 2018). The results of our studies confirmed the positive effect of the Rumit preparation on protective abilities of the organism and the health condition of cows during the first 100 days after calving.

\section{Conclusion}

The conducted studies indicate the positive effect of the Rumit probiotic, which is based on cellulolytic bacteria. Once in the organism, the biopreparation produces biologically active substances and hydrolytic enzymes that provide splitting of nutrients of feed, improve digestibility and increase in absorption of the nutrients. During feeding, the probiotic contributed to inhabitation of the gastrointestinal tract by normal microflora, thus preventing the development of conditionally pathogenic microflora and relieving animals from possible diseases. Use of the Rumit enzyme probiotic preparation in feeding lactating cows led to increase in the feeding activity and inhabitation of the animals' rumen by ciliates, normalizing of the metabolic processes and increase in natural resistance of firstcalf heifers and ultimately to increase in dairy productivity and reduction of costs for feed and the production. The data obtained in the process of the study confirm the efficiency of the biopreparation and allow us to recommend it to be used in feeding fresh cows. Studying the effect of the probiotic drug on the parameters of health and productivity will be continued taking into account age, physiological group and breed of animals.

\section{References}

Abrunhosa, L., Inês, A., Rodrigues, A. I., Guimarães, A., Pereira, V. L., Parpot, P., \& Venâncio, A. (2014). Biodegradation of ochratoxin A by Pediococcus parvulus isolated from Douro wines. International Journal of Food Microbiology, 188, 45-52.

Al Zahal, O., Mc Gill, H., Kleinberg, A., Holliday, J. I., Hindrichsen, I. K., Duffield, T. F., \& Mc Bride, B. W. (2014). Use of a direct-fed microbial product as a supplement during the transition period in dairy cattle. Journal of Dairy Science, 97(11), 7102-7114

Alter, M. J., Arduino, M. J., Lyerla, H. C., Miller, E. R., \& Tokars, J. I. (2001). Recommendations for preventing transmission of infections among chronic hemodialysis patients. Morbidity and Mortality Weekly Report, 50, 1-43.

Angelakis, E. (2017). Weight gain by gut microbiota manipulation in productive animals. Microbial Pathogenesis, 106, 162-170.

Bajaj, B. K., Claes, I. J., \& Lebeer, S. (2021). Functional mechanisms of probiotics. Journal of Microbiology, Biotechnology and Food Sciences, 2021, 321-327.

BiernasiakJ., ŚliżewskaK., \& Libudzisz, Z. (2011). Feeds with probiotics in animal's nutrition. In: El-Shemy, H. (Ed.). Soybean and Nutrition. IntechOpen. Pp. 181-200.

Boris, S., \& Barbés, C. (2000). Role played by lactobacilli in controlling the population of vaginal pathogens. Microbes and Infection, 2(5), 543-546.

Burkin, A. A., \& Kononenko, G. P. (2014). Secondary fungal metabolites (mycotoxins) in lichens of different taxonomic groups. Biology Bulletin of the Russian Academy of Sciences, 41, 216-222.

Casewell, M., Friiis, C., Marco, E., McMullin, P., \& Phillips, I. (2003). The European ban on growth-promoting antibiotics and emerging consequences for human and animal health. Journal of Antimicrobial Chemotherapy, 52(2), 159-161.
Cho, K. M., Math, R. K., Hong, S. Y., Islam, S. M. A., Mandanna, D. K., Cho, J. J., \& Yun, H. D. (2009). Iturin produced by Bacillus pumilus HY1 from Korean soybean sauce (kanjang) inhibits growth of aflatoxin producing fungi. Food Control, 20(4), 402-406.

Farkhutdinova, A. R. (2020). Vliyanie probioticheskogo preparata "Biolaks-u" na morfobiohimicheskie pokazateli krovi korov [The influence of the probiotic preparation "Biolax-u" on the morphobiochemical parameters of the blood of cows]. Kormlenie Sel'skohozyajstvennyh Zhivotnyh i Kormoproizvodstvo, 7 , 70-76 (in Russian).

Gerasimenko, A. A., Sokolov, M. Y., Belyaeva, N. Y., \& Ashenbrenner, A. I. (2015). Ocenka vliyaniya probiotiko-fermentnyh preparatov na biohimicheskie pokazateli krovi korov v razdoe [Evaluation of the effect of probiotic-enzyme preparations on the biochemical parameters of the blood of cows in milk production]. Vestnik Altajskogo Gosudarstvennogo Agrarnogo Universiteta, 125, 97-101 (in Russian).

Godziszewska, J., Pogorzelska-Nowicka, E., Brodowska, M., Jagura-Burdzy, G., \& Wierzbicka, A. (2018). Detection in raw cow's milk of coliform bacteria-reservoir of antibiotic resistance. Lwt, 93, 634-640.

Lagun, A. A., \& Smimova, L. V. (2015). Pishchevoe povedenie vysokoproduktivnyh korov pri optimizacii ih pitaniya kormovoj dobavkoj TASCO [Feeding behavior of high-yielding cows while optimizing their nutrition with TASCO feed additive]. In: Problemy i perspektivy innovacionnogo razvitiya agrotekhnologij: Materialy XIX Mezhdunarodnoj Nauchno-proizvodstvennoj Konferencii. Belgorodskij GAU, Belgorod. Pp. 177-178 (in Russian).

Laptev, G. Y., Novikova, N. I., Ilyina, L. A., Yildirim, E. A., Nagornova, K. V., Dumova, V. A., Soldatova, V. V., Bolshakov, V. N., Gorfunkel, E. P., Dubrovina, E. G., Sokolova, O. N., Nikonov, I. N., \& Lebedev, A. A. (2014). Normy soderzhaniya mikroflory v rubce krupnogo rogatogo skota [Norms of microflora content in the rumen of cattle]. Biotrof, Saint Petersburg (in Russian).

Liu, H., Ji, H. F., Zhang, D. Y., Wang, S. X., Wang, J., Shan, D. C., \& Wang, Y. M. (2015). Effects of Lactobacillus brevis preparation on growth performance, fecal microflora and serum profile in weaned pigs. Livestock Science, 178, 251-254.

Luzina, O. A., \& Salakhutdinov, N. F. (2016). Biological activity of usnic acid and its derivatives. Part 2. Effects on higher organisms. Molecular and Physicochemical aspects. Russian Journal of Bioorganic Chemistry, 42, 249-268.

Ma, T., Suzuki, Y., \& Guan, L. L. (2018). Dissect the mode of action of probiotics in affecting host-microbial interactions and immunity in food producing animals. Veterinary Immunology and Immunopathology, 205, 35-48.

Maamouri, O., Selmi, H., \& M'hamdi, N. (2014). Effects of yeast (Saccharomyces cerevisiae) feed supplement on milk production and its composition in Tunisian Holstein Friesian cows. Scientia Agriculturae Bohemica, 45(3), 170-174.

Markin, Y. (2016). Probiotiki - eto zhivaya fabrika fermentov [Probiotics are a living enzyme factory]. Zhivotnovodstvo Rossii, 6, 4445 (in Russian).

Masalov, V. N., Lyakhova, O. L., \& Sysoeva, L. A. (2018). Vliyanie probiotika "Bio20 " na pokazateli fagocitarnoj i baktericidnoj aktivnosti nejtrofilov korov i telyat [Influence of probiotic “Bio-20" on indicators of phagocytic and bactericidal activity of neutrophils in cows and calves]. Mezhdunarodnyj Zhurnal Prikladnyh i Fundamental'nyh Issledovanij, 12(1), 88-92 (in Russian).

Mullins, C. R., Mamedova, L. K., Carpenter, A. J., Ying, Y., Allen, M. S., Yoon, I., \& Bradford, B. J. (2013). Analysis of rumen microbial populations in lactating dairy cattle fed diets varying in carbohydrate profiles and Saccharomyces cerevisiae fermentation product. Journal of Dairy Science, 96(9), 5872-5881.

Nekrasov, R. V., Chabaev, M. G., Anisova, N. I., Anikin, A. S., Gadzhiev, A. M., \& Ushakova, N. A. (2013). Probiotik novogo pokoleniya v kormlenii korov [New generation probiotic in cow feeding]. Dostizheniya Nauki i Tekhniki APK, 3, $38-40$ (in Russian).

Nesme, J., \& Simonet, P. (2015). The soil resistome: A critical review on antibiotic resistance origins, ecology and dissemination potential in telluric bacteria. Environmental Microbiology, 17(4), 913-930.

Oh, J., Harper, M., Melgar, A., Compart, D. P., \& Hristov, A. N. (2019). Effects of Saccharomyces cerevisiae-based direct-fed microbial and exogenous enzyme products on enteric methane emission and productivity in lactating dairy cows. Journal of Dairy Science, 102(7), 6065-6075.

Parker, R. (2014). Probiotics, the other half of the antibiotic story. Animal Nutrition and Health, 29, 4-8.

Pereira, R., Bortoluzzi, C., Durrer, A., Fagundes, N. S., Pedroso, A. A., Rafael, J. M., Perim, J. E. L., Zavarize, K. C., Napty, G. S., Andreote, F. D., Costa, D. P., \& Menten, J. F. M. (2019). Performance and intestinal microbiota of chickens receiving probiotic in the feed and submitted to antibiotic therapy. Journal of Animal Physiology and Animal Nutrition, 103(1), 72-86.

Reddy, K. R. N., Reddy, C. S., \& Muralidharan, K. (2009). Potential of botanicals and biocontrol agents on growth and aflatoxin production by Aspergillus flavus infecting rice grains. Food Control, 20(2), 173-178.

Romanov, V. N., Bogolyubova, N. V., Laptev, G. Y., \& Ilyina, L. A. (2019). Sovremennye sposoby uluchsheniya zdorovya i rosta produktivnosti zhvachnyh zhivotnyh [Modem ways to improve the health and productivity of ruminants]. FGBNU FNC VIZH imeni L. K. Ernsta, Dubrovicy (in Russian). 
Schofield, B. J., Lachner, N., Le, O. T., McNeill, D. M., Dart, P., Ouwerkerk, D. Hugenholtz, P., \& Klieve, A. V. (2018). Beneficial changes in rumen bacterial community profile in sheep and dairy calves as a result of feeding the probiotic Bacillus amyloliquefaciens H57. Journal of Applied Microbiology, 124(3), 855-866.

Smirnova, Y. M., Litonina, A. S., \& Platonov, A. V. (2020). Effektivnost' ispol'zovaniya probiotikov v kormlenii dojnyh korov [Efficiency of using probiotics in feeding milk cows]. Vestnik KrasGAU, 162, 145-150.

Sundset, M. A., Edwards, J. E., Cheng, Y. F., Senosiain, R. S., Fraile, M. N., Northwood, K. S., \& Wright, A. D. G. (2009). Rumen microbial diversity in Svalbard reindeer, with particular emphasis on methanogenic archaea. FEMS Microbiology Ecology, 70(3), 553-562.

Syrtsev, A. (2019a). Probiotik v racione vysokoproduktivnyh korov v period razdoya [A probiotic in the diet of high-yielding cows during the milking period]. Kombikorma, 3, 69-71 (in Russian).

Syrtsev, A. (2019b). Vliyanie probiotika na biohimicheskie pokazateli krovi korov v period razdoya [Influence of a probiotic on the biochemical parameters of the blood of cows during the milk period]. Kombikorma, 5, 75-76 (in Russian).

Valitova, A. A., Mironova, I. V., \& Islamova, M. M. (2014). Effektivnost' ispol'zovaniya probioticheskoj dobavki "Vetosporin-aktiv" pri proizvodstve moloka [Efficiency of using probiotic additive "Vetosporin-active" in milk production]. Vestnik Bashkirskogo Gosudarstvennogo Agrarnogo Universiteta, 1, 45-50 (in Russian).
Vorobieva, N. V., \& Popov, V. S. (2020). Vliyanie kormovoj dobavki s probiotikom na povyshenie produktivnosti i stimulyaciyu metabolizma u korov [Effect of the feed additive with probiotic on increasing productivity and stimulating metabolism in cows]. Dostizheniya Nauki i Tekhniki APK, 34(3), 75-78 (in Russian).

Wemette, M., Safi, A. G., Wolverton, A. K., Beauvais, W., Shapiro, M., Moroni, P., Welcome, F. L., \& Ivanek, R. (2021). Public perceptions of antibiotic use on dairy farms in the United States. Journal of Dairy Science, 104, 3.

Xu, H., Huang, W., Hou, Q., Kwok, L. Y., Sun, Z., Ma, H., Zhao, F., Lee, Y. K., \& Zhang, H. (2017). The effects of probiotics administration on the milk production, milk components and fecal bacteria microbiota of dairy cows. Science Bulletin, 62(11), 767-774.

Yadav, S., \& Jha, R. (2019). Strategies to modulate the intestinal microbiota and their effects on nutrient utilization, performance, and health of poultry. Journal of Animal Science and Biotechnology, 10(1), 1-11.

Yu, Y. J., Amorim, M., Marques, C., Calhau, C., \& Pintado, M. (2016). Effects of whey peptide extract on the growth of probiotics and gut microbiota. Joumal of Functional Foods, 21, 507-516.

Yuan, K., Liang, T., Muckey, M. B., Mendonça, L. G. D., Hulbert, L. E., Elrod, C. C., \& Bradford, B. J. (2015). Yeast product supplementation modulated feeding behavior and metabolism in transition dairy cows. Journal of Dairy Science, 98(1), 532-540. 